\title{
Breast Cancer: Epidemiological, Clinical, and Therapeutic Aspects in Pointe Noire (Congo Brazzaville)
}

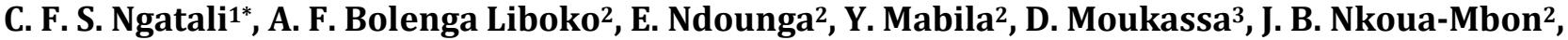 \\ P. E. G. Sounga Bandzouzi4, L. M. A. Boumba ${ }^{5}$
}

\author{
${ }^{1}$ Department of Oncology and Internal Medicine, Loandjili General Hospital, Pointe Noire, Congo \\ ${ }^{2}$ Medical Oncology Department, CHU-Brazzaville, Brazzaville, Congo \\ ${ }^{3}$ Hospital General Edith Lucie Bongo, Oyo, Congo \\ ${ }^{4}$ Departement of Neurology, Loandjili General Hospital, Pointe Noire, Congo \\ ${ }^{5}$ Laboratoire d'Anatomie Pathologie, Loandjili General Hospital, Pointe Noire, Congo \\ Email: *christianngatali2003@yahoo.fr
}

How to cite this paper: Ngatali, C.F.S., Liboko, A.F.B., Ndounga, E., Mabila, Y., Moukassa, D., Nkoua-Mbon, J.B., Bandzouzi, P.E.G.S. and Boumba, L.M.A. (2019) Breast Cancer: Epidemiological, Clinical, and Therapeutic Aspects in Pointe Noire (Congo Brazzaville). Open Journal of Pathology, 9, 76-85.

https://doi.org/10.4236/ojpathology.2019.9 $\underline{4009}$

Received: June 4, 2019

Accepted: September 27, 2019

Published: September 30, 2019

Copyright $\odot 2019$ by author(s) and Scientific Research Publishing Inc. This work is licensed under the Creative Commons Attribution-NonCommercial International License (CC BY-NC 4.0). http://creativecommons.org/licenses/by-nc/4.0/ (c) (i) \& Open Access

\begin{abstract}
Introduction: Breast cancer is the leading cancer and the leading cause of cancer death in women worldwide. The objective of our study was to describe the epidemiological, clinical and therapeutic aspects of breast cancer at the General Hospital of Loandjili in Pointe Noire. Patients and Methods: This was a descriptive and cross-sectional study that took place in the Cancer Department of the General Hospital of Loandjili in Pointe Noire during the period from January 1st, 2012 to December 31st, 2016 for duration of 5 years. 54 records of patients over 18 years of age with histological evidence were collected. The variables studied were: age, level of education, time to presentation, telltale sign, stage of extension, histological type, and histological grade. Chi-square test was used to compare variables and groups. Results: At the end of this study, we collected 54 files of breast cancer patients from $150 \mathrm{pa}-$ tients hospitalized in the Cancer Department. The frequency of breast cancer was $36 \%$. The average age was $50 \pm 13.6$ years; the extremes were 27 years and 79 years. The most represented age group was from 37 to 40 years old with a percentage of $28 \%$. The patient's level of study was primary in the majority of cases (57\%). The most represented histological type was invasive ductal carcinoma, (100\%). The majority of patients arrived at advanced stages $44.4 \%$ and metastatic stages $26 \%$. Patients were treated in most of cases by chemotherapy (82\%), surgery (42\%) and radiotherapy (10\%). There was a correlation between time of presentation and stage of extension. Conclusion: Breast cancer is the first cancer of the woman in Pointe Noire. Patients arrive at advanced stages; the most common histological type is invasive ductal carcino-
\end{abstract}


ma. The presentation time is correlated with the extension stage. These results suggest the establishment of a cancer control program in developing countries.

\section{Keywords}

Epidemiological, Clinical, Therapeutic, Breast Cancer, Pointe Noire

\section{Introduction}

Breast cancer is the leading cancer and the leading cause of cancer death in women worldwide [1]-[16]. This pathology was diagnosed in women at a frequency of $24.2 \%$ and was responsible for nearly $15 \%$ of deaths in 2018 [3]. In developing countries it is the first cancer diagnosed and the leading cause of cancer death in women [2]. In these low-income countries, breast cancer is often diagnosed at advanced stages and has a poor prognosis [6]. Breast cancer affects both men than women [17]-[21]. Since the publication of Moukassa et al. in 2007 that ranked breast cancer in second place of cancer in Pointe Noire in Congo, no studies have yet been performed [20]. Our study aimed to determine the epidemiological, clinical and therapeutic aspects of breast cancer in Pointe Noire.

\section{Patients and Methods}

This was a cross-sectional descriptive study that took place in the oncology department of loandjili General Hospital in Pointe Noire in the period from 1st January 2012 to 31st December 2016, a period of 5 years. Were included in our study: all patients old more than 18 years, all patients having a complete file that is to say comprising a histological diagnosis and an extension assessment performed using an abdominal CT scan. Were excluded from our study all patients with no histological diagnosis. All men with breast cancer were excluded. The variables studied were:

- Sociodemographic parameters: age, level of education, time of presentation;

- Clinical parameters revealing sign, stage of extension;

- Histological type and histological grade;

- The type of treatment.

The time of presentation or delay was long when it was longer than 6 months and short when it was less than 6 months and was defined as the time elapsing between the installation of the disease or signs and the diagnosis. The stage of extension was grouped in local (stage 0 and I), locoregional or advanced (stage II and III) and metastatic for stage IV.

The collection of data was made from a previously written survey sheet, containing the different variables studied. The multivariate analysis was done between the time of presentation, the stage of extension and the age. Data entry was 
done using the Excel version 2007 software. Qualitative variables were represented in terms of number and percentage. Quantitative variables were represented effective and on average. The statistical analysis and the data processing were carried out by the Excel 2007 software and the graphpad prism version 5 software. The statistical test used was the chi-square test.

\section{Results}

During this study we collected 150 women cancer patients' records. Of the 150 files, 54 files had met the inclusion criteria of our study, so the frequency in our study of breast cancer in women was $36 \%$. The patients were followed from the date of diagnosis to the date of study, from January 1st, 2012 to December 31st, 2016 for a period of 5 years in the oncology department.

The average age of the patients was $50.35 \pm 13.6$ years. The extremes were 27 years and 79 years old. The most represented age group was the age group from 37 to 46 years with 18 cases or $33.33 \%$ (Table 1 ).

The most represented level study in our study was the primary level $63 \%$, followed by secondary level $26 \%$ and the upper or superior level $11 \%$ (Table 2).

The average time to presentation at the consultation was $7.01 \pm 1.48$ months. $76 \%$ of patients had a long delay, $24 \%$ of patients had a short delay in our study (Table 3).

The most frequent telltale sign was the breast nodule in 52 cases, or $96.3 \%$ of cases. The rest of the telltale sign was represented by 1 case of wide, purulent and necrotic ulceration of the breast (Figure 1) and 1 case of inflammatory breast. The most common histological type represented was invasive ductal carcinoma $100 \%$. The most represented histological grade was grade III of Scarff Bloom Richardson (59.3\%), followed by grade II $22.2 \%$ and grade I in $18.5 \%$ of cases (Figure 2). The majority of patients presented at locoregional stage in $44.4 \%$ of cases; local stage was represented in $25.5 \%$ of cases while the metastatic stage was represented in $26 \%$ of cases (Table 4 ). The most represented treatment was chemotherapy ( $82 \%$ ) followed by surgery in $48 \%$ of cases, radiotherapy $18 \%$ of cases; no patient had been treated with hormone therapy (Table 5).

Patients who had a long presentation time had a local stage in $9.76 \%$ of cases, locoregional stage in $51.22 \%$ of cases and metastatic stage in $39.02 \%$ of cases while patients who had a short time of presentation had more local stages in 77\% of cases, $23 \%$ of cases of stage locoregional and $0 \%$ stage cases metastatic.

The correlation was found between the time of presentation and the stage of extension of the disease. The longer time of presentation was, the more the stage of extension was advanced or metastatic. This result was statistically significant $(\mathrm{p}<0.05)$ (Table 6).

Comparison of patients younger than 40 years old to patients over 40 years old has allowed to note that breast cancer incidence was highest at all stages in the women over than 40 years old. There was no correlation between age and stage of extension ( $p>0.05)$ (Table 7). 


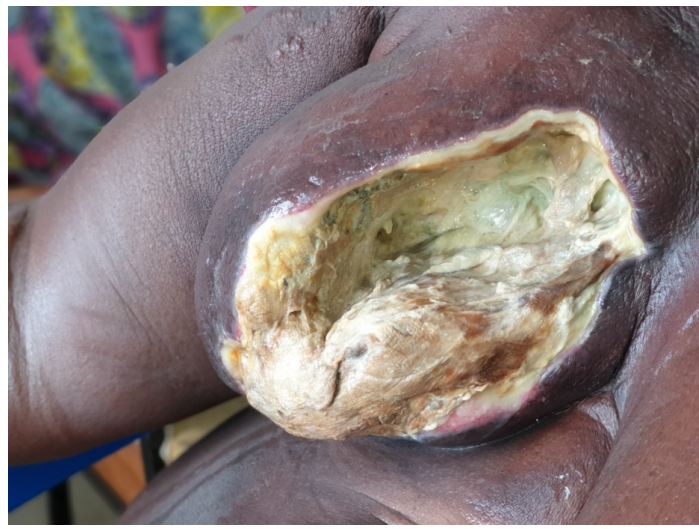

Figure 1. Wide, deep and purulent breast ulceration.

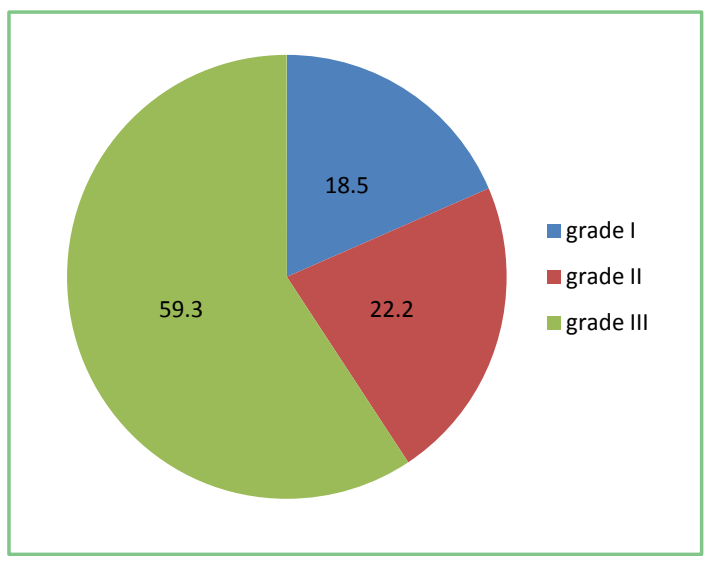

Figure 2. Distribution patients according to histological grade.

Table 1. Distribution of patients according to age group.

\begin{tabular}{ccc}
\hline Age group & Effective & Percentage \\
\hline $27-36$ & 6 & 11.11 \\
$37-46$ & 18 & 33.33 \\
$47-56$ & 12 & 22.22 \\
$57-66$ & 10 & 18.51 \\
$67-76$ & 7 & 13 \\
$77-86$ & 1 & 1.85 \\
Total & 54 & 100 \\
\hline
\end{tabular}

Table 2. Distribution of patients according to level of study.

\begin{tabular}{ccc}
\hline Level of study & Effective & Percentage \\
\hline Primary & 34 & 63 \\
Secondary & 14 & 26 \\
Superior & 6 & 11 \\
Total & 54 & 100 \\
\hline
\end{tabular}


Table 3. Distribution of patients according to the consultation time.

\begin{tabular}{ccc}
\hline Time of presentation & Effective & Percentage \\
\hline Short & 13 & 24 \\
Long & 41 & 76 \\
Total & $\mathbf{5 4}$ & $\mathbf{1 0 0}$ \\
\hline
\end{tabular}

Table 4. Distribution of patients by stage of extension.

\begin{tabular}{ccc}
\hline Stage of extension & Effective & percentage \\
\hline Local & 14 & 25.5 \\
Locoregional & 24 & 44.4 \\
Metastatic & 16 & 26 \\
Total & 54 & 100 \\
\hline
\end{tabular}

Table 5. Distribution of patients according to treatment.

\begin{tabular}{ccc}
\hline Treatment & Yes & no \\
\hline Surgery & $26(48 \%)$ & $28(52 \%)$ \\
Chemotherapy & $44(82 \%)$ & $10(18 \%)$ \\
Radiotherapy & $10(18 \%)$ & $44(82 \%)$ \\
Hormonetherapy & $0(0 \%)$ & $0(0 \%)$ \\
\hline
\end{tabular}

Table 6. Distribution of patients by consultation time and extension stage.

\begin{tabular}{ccccc}
\hline & \multicolumn{4}{c}{ Stage of Extension } \\
\hline Time of presentation & Local & Locoregional & Metastatic & Total \\
\hline Short & $10(77 \%)$ & $3(23 \%)$ & $0(0 \%)$ & $13(100 \%)$ \\
Long & $4(9.76 \%)$ & $21(51.22 \%)$ & $16(39.02 \%)$ & $41(100 \%)$ \\
Total & 14 & 24 & 16 & 54 \\
\hline
\end{tabular}

$\mathrm{P}<0.05$ test statistically significant.

Table 7. Distribution of patients by age and stage of extension.

\begin{tabular}{ccccc}
\hline \multicolumn{5}{c}{ Stage of extension } \\
\hline Age & Local & Locoregional & Metastatic & Total \\
\hline Age $<40$ & $5(31.25 \%)$ & $9(56.25 \%)$ & $2(12.5 \%)$ & $16(29.7 \%)$ \\
Age $>40$ & $9(23.7)$ & $15(39.5 \%)$ & $14(36.8 \%)$ & $38(70.37 \%)$ \\
Total & 14 & 24 & 16 & 54 \\
\hline
\end{tabular}

p $>0.05$ statistically insignificant result.

\section{Discussion}

Our study presented some limitations. Indeed, the sample size of our hospital study was small. The lack of immunohistochemistry has failed to achieve the molecu- 
lar classification that should determine the prognostic and predictive factors of breast cancer. Despite of this small sample, this study has described some epidemiological, clinical and therapeutic aspects of breast cancer in Pointe Noire which is a city of about one million inhabitants.

During our study, which took place at the General Hospital of Loandjili in the Cancer Department, we received a total of 150 women cancer patients.

Of the 150 patients, 54 had breast cancer and met all the inclusion criteria of our study. Thus, the incidence of breast cancer in women during our study was $36 \%$.

Breast cancer was the first cancer of women in our study as in many studies [2] [3].

The average age of the patients in our study was $50.35 \pm 13.6$ years; the extremes were 27 years and 79 years. Women were affected at a relatively young age, this was also found by most authors in developing countries (Africa) with the averages age of $47.5 \pm 12.36$ and 47.97 described respectively by Ngowa J. et al. [22] and Cameroon and Mensah et al. in Ghana [23]. In developed countries in the US for example, the average age was 61 years old with the extremes of 55 years and 64 years [24]. In Saudi Arabia the average age found was also relatively young $47.16 \pm 12.15$ [25]. The age group most represented in our study was 37 to 46 years of age, followed by the age group 47 to 56 , these age groups were also young.

These age groups were close to the age groups of the majority of African countries [22] [23]. In the USA, the most affected age group was 54 to 65 [24]. Age groups in both developed countries are quite high age groups, unlike age groups in African countries. This could be explained on the one hand by the composition of the African population which is a young population and on the other hand by the probable increase in the incidence of breast cancer in this age group, but also by the development of diagnostic and therapeutic techniques. Indeed, the population of developed countries is aging and age is a risk factor for breast cancer.

The most represented level of education in our study was the primary level in $63 \%$ of cases, followed by the secondary level. In developing countries, patients had a primary level of education or were illiterate [26], whereas in developed countries, particularly in the US, the highest level of education is the highest level [27] [28].

The presentation time in our study was long in the majority of cases $76 \%$, with an average of $7.01 \pm 1.048$ months. Other studies also found a long delay with an average delay of $13 \pm 8$ months [29].

This could be explained on the one hand by a primary level of study in our study thus generating a low knowledge of cancer pathology and early clinical signs; on the other hand the low socio-economic level may be considered as a barrier to consultation since access to a health center and cancer care remains very expensive [30] [31]. 
The most prominent revealing sign was a breast nodule in the majority of cases (98\% of cases); the rest was represented by a large and purulent ulceration of breast aspect (1\%) and an inflammatory breast aspect (1\%).

The predominance of breast mass or breast nodule has been found in the literature [22] [29] [32].

The histological type most represented in our study was $100 \%$ invasive ductal carcinoma. These results are identical to those of the literature [25] [32].

The histological grade III according to Bloom Richardson's scarff grading was the most represented in our study with $59.22 \%$ of cases. The literature has also found a predominance of grade III [25] [32]. The breast cancer seen in our study appeared to be aggressive and therefore poor prognosis.

The majority patients were seen in advanced stages II and III (locoregional) with a percentage of $44.4 \%$ and metastatic $26 \%$ of cases, the local stages accounted for $14 \%$ of cases in our study. Several studies in developing countries have similar results to those of our study [22] [26]. The work of Al. Isawi et al. in Saudi Arabia, found a predominance of advanced stages [25]. Percentages ranging from $31 \%$ to $75 \%$ have been found in Nigeria, Peru, Libya and Brazil [33]. In our study and in most developing countries, patients present with advanced and metastatic whereas in developed or industrialized countries such as Canada, Norway, Great Britain and Sweden, patients present themselves at local stage. Only $8 \%$ to $22 \%$ of patients are diagnosed at advanced stages in these developed countries [34].

The most common treatment used in our study was chemotherapy in $52 \%$ of cases, followed by surgery in $48 \%$ of cases and a radical mastectomy in $100 \%$ of cases.

The presentation at the advanced or metastatic stages of the disease would be a factor favoring the use of chemotherapy in neo-adjuvant situation when the tumor was not operable immediately or in an adjuvant situation when the tumor had pejorative prognostic factors, is it the cases of the histological grade in our study which was the grade III and the stage of extension. According to the work of Ngowa et al. in Cameroon, surgery was used in (64.70\%) cases; the chemotherapy was used in neo-adjuvant (53.39\%) or adjuvant (35.74\%) [22]. As radiotherapy was not available in the Congo, only $10 \%$ of patients were able to benefit abroad in our study.

No patient had been able to receive hormone therapy since none had been able to benefit from immunohistochemistry for the search for hormonal receptors because the technique was not available at that time in Congo.

Multivariate analysis between the presentation time and the extension stage in our study found that the longer the delay, the more advanced the stage. There was a correlation between the two variables (the delay and the extension stage).

These results were statistically significant.

Long presentation times are associated with poor prognosis [34].

Breast cancer affects young women as well as older women. Age is a risk factor. As you get older, the risk of developing breast cancer increases [35]. In our 
study we found 16 cases of breast cancer in patients under 40 years of age and 38 cases of breast cancer in patients over 40 years of age. As age increases, cancer risk increases.

In our study, women over the age of 40 tended to present themselves at advanced stages.

\section{Conclusion}

Breast cancer is the first cancer of the women in Pointe Noire; it affects both young women and older women. The most frequent histological type is invasive ductal carcinoma; patients often consult at advanced stages. The presentation at the advanced stages should lead to the establishment of prevention programs for the fight against cancer in the majority of developing countries.

\section{Conflicts of Interest}

The authors declare no conflicts of interest regarding the publication of this paper.

\section{References}

[1] Ministry of Health (2010) Beat Breast Cancer. United Arab Emirates.

[2] Jemal, A., Bray, F., Center, M.M., et al. (2011) Global Cancer Statistics. CA: A Cancer Journal for Clinicians, 61, 69-90. https://doi.org/10.3322/caac.20107

[3] Bray, F., Ferlay, J., Soerjomataram, I., Siegel, R.L., Torre, L.A. and Jemal, A. (2018) Global Cancer Statistics: GLOBOCAN Estimates of Incidence and Mortality Worldwide for 36 Cancers in 185 Countries. CA: A Cancer Journal for Clinicians, 68, 394-424. https://doi.org/10.3322/caac.21492

[4] Gullatte, M., Phillips, J. and Gibson, L. (2006) Factors Associated with Delays in Screening of Self-Detected Breast Changes in African-American Women. Journal of National Black Nurses' Association, 17, 45-50.

[5] Brahim, N.A. and Odusanya, O.O. (2009) Knowledge of Risk Factors, Beliefs and Practices of Female Healthcare Professionals towards Breast Cancer in a Tertiary Institution in Lagos, Nigeria. BMC Cancer, 9, 76. https://doi.org/10.1186/1471-2407-9-76

[6] Lauby-Secretan, B., Scoccianti, C., Loomis, D., Benbrahim-Tallaa, L., Bouvard, V., Bianchini, F., Straif, K. and International Agency for Research on Cancer Handbook Working Group (2015) Breast-Cancer Screening_Viewpoint of the IARC Working Group. The New England Journal of Medicine, 372, 2353-2358. https://doi.org/10.1056/NEJMsr1504363

[7] Assi, H.A., Khoury, K.E., Dbouk, H., Khalil, L.E., Mouhieddine, T.H. and El Saghir, N.S. (2013) Epidemiology and Prognosis of Breast Cancer in Young Women. Journal of Thoracic Disease, 5, S2-S8.

[8] American Cancer Society (2008) Cancer Facts and Figures.

[9] American Cancer Society (2014) Cancer Facts and Figures 2014. American Cancer Society, Atlanta, GA.

[10] Ferlay, J., Shin, H.R., Bray, F., Forman, D., Mathers, C. and Parkin, D.M. (2010) Women and Cancer: Screening and Treatment Save Lives Estimates of Worldwide Burden of Cancer in 2008: GLOBOCAN 2008. International Journal of Cancer, 127 
2893-2917. https://doi.org/10.1002/ijc.25516

[11] Siegel, R.L., Miller, K.D. and Jemal, A. (2015) Cancer Statistics. CA: A Cancer Journal for Clinicians, 65, 5-29. https://doi.org/10.3322/caac.21254

[12] Ly, D., Forman, D., Ferlay, J., Brinton, L.A. and Cook, M.B. (2013) An International Comparison of Male and Female Breast Cancer Incidence Rates. International Journal of Cancer, 132, 1918-1926. https://doi.org/10.1002/ijc.27841

[13] Bewtra, C. (2010) Clinicopathologic Features of Female Breast Cancer in Kumasi, Ghana. International Journal of Cancer Research, 6, 154-160. https://doi.org/10.3923/ijcr.2010.154.160

[14] International Agency for Research on Cancer (2010) GLOBOCAN Cameroon Fact Sheets: Breast Cancer. Lyon, France. http://globocan.iarc.fr/

[15] Parkin, D.M., Bray, F., Ferlay, J. and Pisani, P. (2005) Global Cancer Statistics, 2002. CA: A Cancer Journal for Clinicians, 55, 74-108. https://doi.org/10.3322/canjclin.55.2.74

[16] Wiredu, E.K. and Armah, H.B. (2006) Cancer Mortality Patterns in Ghana: A 10-Year Review of Autopsies and Hospital Mortality. BMC Public Health, 6, 159-165. https://doi.org/10.1186/1471-2458-6-159

[17] Moukassa, D., Ibara, J.R., Benali, A., N'koua-Mbon, J.B., Bikindou, A.S., Lingouala, L.G., Tsiba, J.R., Eouany, M.L., Diembi, S. and Dykoka-N'golo, R. (2007) Le profil épidémiologiques des cancers A-T-IL évolué en cinquante ans a Pointe Noire au Congo Brazzaville? Médecine d'Afrique Noire, 5401, 29.

[18] Togo, A., Kante, L., Dembele, B.T., Traore, A., Diakite, I., Maigra, A., Diallo, A.C. and Diallo, G. (2010) Cancer du sein dans deux centre hospitaliers de Bamako. Aspects épidémiologiques et diagnostiques. Médecine d Afrique Noire, 5705, 249-253.

[19] Moukassa, D., Mvoukoulou, B., N'koua-M’bon, J.B., Ebatetou-Ataboho, E. and Koukambassana, S. (2012) Caracteristiques cyto morphologiques des nodules palpables en consultation médicale ambulatoire. Médecine d Afrique Noire février, 5902, 59-63.

[20] Siegel, R., Naishadham, D. and Jemal, A. (2012) Cancer Statistics 2012. CA: A Cancer Journal for Clinicians, 62, 283-98. https://doi.org/10.3322/caac.21153

[21] Hill, T.D., Khamis, H.J., Tyczynski, J.E. and Berkel, H. (2005) Comparison of Male and Female Breast Cancer Incidence Trends, Tumor Characteristics, and Survival. Annals of Epidemiology, 15, 773-780. https://doi.org/10.1016/j.annepidem.2005.01.001

[22] Ngowa, J., Kasia, J., Yomi, J., Nana, A., Ngassam, A., Domkam, I., Sando, Z. and Ndom, P. (2015) Breast Cancer Survival in Cameroon: Analysis of a Cohort of 404 Patients at the Yaoundé General Hospital. Advances in Breast Cancer Research, 4, 44-52. https://doi.org/10.4236/abcr.2015.42005

[23] Mensah, A., Yarney, J., Nokoe, S., Opoku, S. and Clegg-Lamptey, J. (2016) Survival Outcomes of Breast Cancer in Ghana: An Analysis of Clinicopathological Features. Open Access Library Journal, 3, 1-11.

[24] Rugo, H.S., Majure, M., Buxton, M. and Esserman, L. (2017) Neoplasme of Breast. Cancer Medicine, 9, 1368-1438.

[25] Al-Isawi, A. (2016) Breast Cancer in Western Iraq: Clinicopathological Single Institution Study. Advances in Breast Cancer Research, 5, 83-89. https://doi.org/10.4236/abcr.2016.52009

[26] Gueye, M., Gueye, S., Diallo, M., Thiam, O., Mbodji, A., Diouf, A., Fall, K., Toure, Y., Daff, H. and Moreau, J. (2017) Sociodemographic Factors Associated with Delays in Breast Cancer. Open Journal of Obstetrics and Gynecology, 7, 455-463. 
https://doi.org/10.4236/ojog.2017.74047

[27] Dieterich, M., Stubert, J., Reimer, T., et al. (2014) Influence of Life Style Factors on Breast Cancer Risk. Breast Cancer, 9, 407-414. https://doi.org/10.1159/000369571

[28] Cuzick, J. (2008) Assessing Risk for Breast Cancer. Breast Cancer Research, 10, S13. https://doi.org/10.1186/bcr2173

[29] Mayi-Tsonga, S., Belembaogo, E., Meyé, J.-F., Ngou-Mvé-Ngou, J.-P., Nguizi-Ogoula, S. and Bisse, A. (2009) Les cancers du sein au Gabon: Aspects epidemiologiques, diagnostiques et therapeutiques. Journal africain du cancer, 1, 11-15. https://doi.org/10.1007/s12558-008-0003-y

[30] Abulkhair, O.A., Al Tahan, F.M., Young, S.E., Musaad, S.M. and Jazieh, A.-R.M. (2010) The First National Public Breast Cancer Screening Program in Saudi Arabia. Annals of Saudi Medicine, 30, 350-357. https://doi.org/10.4103/0256-4947.67078

[31] Mukem, S., Sriplung, H., McNeil, E. and Tangcharoensathien, V. (2014) Breast Cancer Screening among Women in Thailand: Analyses of Population Based Household Surveys. Journal of the Medical Association of Thailand, 97, 1106-1118.

[32] Sano, D., Cisse, R., Dao, B., Lankoande, J., Traore, S.S., Soudre, R.B. and Sanou, A. (1998) Le cancer du sein problème diagnostics et thérapeutiques au CHU de Ouagadougou. Médecine d' Afrique Noire, 45, 297-301.

[33] Unger-Saldana, K. (2014) Challenges to the Early Diagnosis and Treatment of Breast Cancer in Developing Countries. World Journal of Clinical Oncology, 5, 465-477. https://doi.org/10.5306/wjco.v5.i3.465

[34] Olivotto, I.A., Gomi, A., Bancej, C., et al. (2002) Influence of Delay to Diagnosis on Prognostic Indicators of Screen-Detected Breast Carcinoma. Cancer, 94, 2143-2150. https://doi.org/10.1002/cncr.10453

[35] Dia, J., Toure, M., Yao, I., Bohoussou, E., Saki, C., Oyelade, M., Okon, G. and Anonga, S. (2017) Breast Cancer in Young Women under 40 Years in Sub-Saharan Africa. Journal of Cancer Therapy, 8, 714-725. 